\title{
Belonging, Strangerhood and Mobility: South Sudanese in a Rural Town, Victoria
}

\author{
Naduni Wickramaarachchi \\ Edgar Burns \\ Department of Social Inquiry, School of Humanities and Social Sciences, La Trobe University \\ Corresponding author: naduniwick@gmail.com
}

Abstract

Australian regional areas are now receiving significant numbers of migrants from the African continent. Predominantly Anglo-Saxon communities perceive these 'newcomers' as physically and culturally different. Asking, however, how African migrants themselves construct relationships with local communities and build a sense of belonging in regional and rural areas is a very different question. This paper explores South Sudanese migrants'experiences conceptualising their sense of belonging in a small county town: Castlemaine, Victoria. Focus group discussions show that even with the welcoming atmosphere and support from the local community, South Sudanese migrants are still attracted to metropolitan environments that have greater diversity, feeling more at home in such settings. Using the theoretical background of a stranger, this paper argues the cities allow strangers be un-noticed letting them feel at 'home'. Findings from the study show settings with greater diversity encourage negotiating difference openly and easing power imbalances among different groups.Finally, the locality of Castlemaine, within easy commuting distance to metropolitan Melbourne and suburbs, is considered in relation to hypermobility reducing the capacity to construct 'bridging capital' within such local communities.

Key words: Migrants, Sense of belonging, Small town, Stranger, South Sudanese 


\section{Introduction}

Australian country sides are now receiving migrants from all around the world as a result of government initiative of settling migrants in regional parts of Australia and also as a cause of voluntary secondary migration (McDonald, Gifford, Webster, Wiseman, \& Casey, 2008). Because of the secondary migration now Australian country sides have started to expose to migrants from the African region, which sometimes may be the first time in the history (Major, Wilkinson, Langat, \& Santoro, 2013). Being physically and culturally different from the predominantly white communities in regional parts of Australia, how African migrants build a sense of belonging is a question.

This paper aims to understand how South Sudanese migrants now living in a small country town in the state of Victoria build their sense of belonging. Further, it aims to explore how the distance and the diversity effect on making a place as at home for migrants. By selecting South Sudanese migrants as the study population, allows hearing the voices of a most marginalised migrants group in Australia (Baak, 2011; Federation of Ethnic Communities' Councils of Australia, 2009) on how they perceive they're belonging to a small town.

\section{Study location}

Regional parts of Australia now started to receive a considerable number of migrants as a result of government policies and programs as well as a factor of voluntary secondary migration (McDonald et al., 2008; Ratnayake, 2017). This trend is accelerated because of the creation of new employment opportunities in some regional areas. Apart from that, affordable housing, escape from urban problems such as racist violence, drug abuse and youth peer pressure have been highlighted as some factors cause for migrants to move out from metropolitan areas (McDonald et al., 2009). In terms of secondary migration, some regional centres have become more popular destinations for migrants from the African continent. Even though it is hard to trace the secondary migration of migrants, few studies have identified some regional centres which have attracted Sudanese migrants in recent past (Australian Human Rights Commission, 2009; Taylor, 2005). Castlemaine, the study location of this study has been identified as one of the regional small towns that started to receive South Sudanese migrants since 2006 (McDonald et al., 2009). Castlemaine is located in Mount Alexandra shair which is 120 kilometres northwest from Melbourne 
metropolitan area. The location facilitates easy connection with Melbourne metropolitan area via Victorian Regional train line (V Line).

The initial arrival of African migrants to Castlemaine was started with four South Sudanese men finding jobs in a meat factory with the help of New Hope Foundation (Jensen, Perry, \& Halastanis, 2007). (New Hope Foundation basically works in the area of providing employment assistance to African refugees living in the western Metropolitan region of Melbourne). Later with these links Sudanese community in Castlemaine started to grow in numbers. At the time when the field work was conducted, there were about sixty-five South Sudanese people living in Castlemaine as families or as individuals. Most of the men live in shared houses while their families live in Melbourne (Western Metropolitan Suburbs). Almost all the South Sudanese who are now living in Castlemaine had lived in some other places in Australia before moving to this regional shire.

\section{Focus group discussions}

Twelve focus group discussions were conducted with South Sudanese migrants with the Latrobe ethics approval. During focus group discussions the researcher attempted to understand how South Sudanese migrants conceptualised their sense of belonging. With that in mind, participants were invited them to talk about the moments and places that they feel as if they being at home. Home marks the ultimate sense of belonging: comfort and security. Here, the home is not defined as material space but used in the meaning of symbolic space of familiarity, comfort, security, and emotional attachment (Hage, 1997).

A pre-study was conducted to understand the community support towards the new South Sudanese arrivals in the study location. As a host community volunteers formed an organisation called, Friends and Tutors of the Sudanese and Burundi of Castlemaine to act mentors and tutors of the newly arrived African community. . A local level newspaper analysis was conducted prior to the Focus group discussions and that evidence shows how news articles have created a positive image of South Sudanese migrants in relation to their integration process in Castlemaine. News articles documented the local support towards Sudanese community in a number of times (Wickramaarachchi \& Burns, 2017). By reflecting this atmosphere it was assumed that South Sudanese migrants feel as at home in Castlemaine. In contrast, during the discussions, participants' experience of being at home led the discussion towards for a comparison between small towns vs. 
big metropolitan areas. The findings directed how a migrant as a stranger reads his environment where it is comfortable, secure or not. This discussion is fueled by the theoretical background of the social theory of Stranger.

\section{Strangers in the city}

The sociological interpretation of the stranger discusses the relationship between a migrant/nonmember and a host and the spatial issues arising from that relationship (Marotta, 2001). This stranger usually refers to a social and cultural other who is normally marginalised or excluded from the host group (Marotta, 2001). In a more radical manifestation, this "in-group" usually consists of western, white males. In this sense, the stranger is more aligned with the racial and cultural other who has been excluded from the white dominant host community.

Bauman brought the discussion of Stanger theory to the cities and explains how new comers read and experience the city environment. In Bauman's (1995a) words, strangers are the people who do not fit the cognitive, moral, or aesthetic map of the world. In this way, strangers both reinforce and blur the boundaries between self and others. Strangers 'befog and eclipse the boundary lines which ought to be clearly seen and spread uncertainty where the certainty and clarity "should" be' (Bauman, 1995b:1).

According to Bauman's writings, the postmodern stranger contains two versions: homelessness and cultural otherness. Contemporary individuals are displaced in a variety of social worlds making them homeless.He suggests two strategies for living with strangers especially in cities. One is to reduce the element of surprise and the unpredictability of the behaviour of the strangers. The other way is to render the elements of what is possible irrelevant and blend the strangers into the background without special notice. When meeting with strangers who are also at the same level, migrants can ease their feeling of inequality in the social order. 'The coexistence of strangers in cities provides part of the model for democratic public life, demonstrating a normative ideal that does not seek to privilege particular subject positions or particular kinds of association' (Young cited in,Horgan, 2012:619). Horgan (2012) interprets this solidarity as soft solidarity.

Horgan (2012:619) notes, 'Soft solidarity is a form that is implicit in relations between strangers when mutuality is recognised and sustained without the requirement for explicit recognition'. In this sense, soft solidarity appears to be a positive element of strangership but it is not enough to 
overcome hard inequalities. Interactions among strangers may exist as a way of diminishing inequalities. They can provide the 'possibilities for an easier co-mingling of difference in the present' (Horgan, 2012, 620). Wise $(2010,918)$ called this as 'rhythms and rhymes of urban diversity' as a part of everyday belonging.

\section{Strangers meet strangers in the city}

The conversations emerging in focus group discussions illustrated the theoretical argument discussed above. When the participants asked to explain where they feel being as at home, most of the participants indicated the areas that in Melbourne Metropolitan areas: such as Footscray and Dandenong. These places were highlighted as the places that their strangeness is un marked and gives them the feeling of equality. In more diverse atmosphere people can step out from their differences and build relationships with each other. As Amin (2002:150) states, these times of being amongst cultural diversity ' are moments of cultural destabilization, offering individuals the chance to break out of fixed relations and fixed notions, and through this, learn to become different through new patterns of social interactions'. Diversity opens the new paths to interrogate with each other without labelling each other as different.

Participants of the study repeatedly mentioned how difference makes them feel comfortable. They referred it to material differences, physical differences, as well as symbolic differences, Among all these difference, South Sudanese do not have to situate themselves as different or as a guest in a host society. A deeper sense of security and homeliness emanates from spaces where the excluding threats of otherness are removed (Grace, Hage, Johnson, Langsworth, \& Symonds, 1997). However, the interactions between strangers create an environment of being at home for migrants may be a temporarily fixed moment. These places cannot be characterized as the places of hospitality but can be understood as places facilitating equal power where no one dominates the relationships.

Negotiating difference and exchanging difference in multi ethnic places is another aspect that participants mentioned as helping them to be comfortable as being at home. This can be seen as distrust, misunderstanding and fear of mark as strangers being overcoming by engaging multiethnic dialogues. Presenting differences can be helpful to open conversation and this can in-turn lead to include others rather than exclude others (Lobo, 2010b). The visible difference on cultural 
goods creates curiosity and invites them to tell stories about stories which link different ways of lives in the world. These interactions open moments of joy, which develop deeper attachments with each other. Even though these moments are not static, they form preconditions for longer relationships and also cultivate a sense of belonging. In their discussion, Zournazi with Hage (2002:162) observe that 'feeling of connection, of sharing, or recognition' are factors that create the feeling of homeliness. Homeliness can be achieved when individuals find a 'more useful and better pursuit for joy in combination with other bodies'. Even though it is argued that the homogeneous environment leads to more stable relationships, multi ethnic places open room for feeling equal and relaxed for migrants. As South Sudanese migrants who live and work in a predominantly white small country town, Castlemaine the participants may have experienced their otherness as a visible factor that undermines their wish to feel at being home.

More divers places like Footscray and Dandenong extend the room for showing their otherness and to be proud about their otherness. Modern cities, where mobility, exchanges and ambivalence exist, provide a space to build homeliness challenging the traditionally viewed home associated with stability, familiarity and orderliness. This sharply contrasts with the phenomenological approach of the home which describes homelessness as a 'destiny of modernity' (Heigegger cited inMarotta, 2008:8). Participants' experiences suggest that modernity can provide a space where strangers could feel at home. Therefore, these findings support the postmodernist view of home as a floating signifier (Bammer, 1992).

\section{Discussion and Conclusion}

The findings of this study lead the discussions into two broad areas: how cities make South Sudanese feel more as at home and how the locality of a small town affect on making mobile community in turn reducing the capacity of building attachments with their local community.

Although the number of studies has pointed out the city space as a place for inter-ethnic relations (Amin, 2002) these studies have not looked at the conditions make it happens. By focusing on the relational aspect between strangers, this paper argues that when strangers meet strangers they all see themselves in an equal power relation without thinking of themselves being excluded from that interaction, and this results in building a feeling of belonging. Using the argument made by Ang (2001:8) that when ethnic groups members see each other they feel that they are in the same 'boat', 
like wise, this paper similarly argues that when strangers see other strangers they feel they are empowered, and also experience pride in this difference that is 'okay'.

The environment in multi ethnic places helps migrants to blend with the surrounding without noticing as different (Horgan, 2012). Very diverse atmosphere like in Foot scary or Dandenong reduces the unexpected surprise that brings by a new comer. The findings of this study supported the arguments that exhibiting and negotiating difference enables people to feel included rather than excluded (Lobo, 2010a, 2010b; Wise \& Velayutham, 2009). But in a more homogeneous society like in Castlemaine still, shows the sharp boundaries of difference and continues to protect the social order. In this environment, South Sudanese may feel their strangerhood and become strangers not only to the outsiders but to themselves too (Ossewaarde, 2007). The findings also suggest the capacity of Stranger theory in understanding how migrants feel and conceptualise belonging in post modern societies.

The location of Castlemaine showed a significant impact on whether the South Sudanese try to build bridging social capital or not with the local community. Castlemaine being located within an easy commuting distance to the Melbourne metropolitan area became a factor in not making more connections with the community where they live now. Castlemaine has experienced new trends of in-migration during the recent past and some studies have pointed out that easy commuting facilities is one of the main reasons for this new demographic change (Butt, 2011). Even though it is a good trend in terms of generating economic and social prospects for the rural areas, it is questionable whether the " "hyper-mobile" societies risk the traditional connections to place' (Butt, 2011,7). Likewise, even though the Sudanese community moved into Castlemaine because of the employment opportunities, they continue their links with the other Sudanese communities very often because of the train lines that connect to metropolitan areas, and as a result, only develop a loose connection with the local community. The frequent travels to non-local areas reduce the time they have to engage with the local community to build bridging networks. 
The findings of the study have some policy implications on how to promote ground level interethnic relationship to build stronger local communities in small country towns. Promoting migrants to settle and remain in rural and regional areas has become a major immigration plan since 1996 in Australia (Wickramaarachchi \& Butt, 2014), Therefore special attention should be taken to build stronger connections between migrants and the local community. To promote inter-ethnic connections it is essential to establish more open public spaces in small country towns. Open spaces like ethnic-diverse market places, restaurants, and cafes provide the spaces for inter ethnic mingling as an everyday ritual. This cannot be implemented only by enforcing policies at the top level. 
References:

Amin, A. (2002). Ethnicity and the multicultural city: Living with diversity. Environment \& Planning A, 34(6), 959-980.

Ang, I. (2001). On not speaking Chinese: Living between Asia and the West. London: Routledge.

Australian Human Rights Commission. (2009). African Australians: Human rights and social inclusion issues. Adelaid: University of Adelaid.

Baak, M. (2011). Diasporic mourning and negotiating belonings in response to murder. Social Alternatives, $30(2), 9-12$.

Bammer, A. (Ed.) (1992). Questions of home. London: Lawrence \& Wishart.

Bauman, Z. (1995a). Life in Fragments. Oxford, UK: Blackwell.

Bauman, Z. (1995b). Making and unmaking of strangers. Thesis Eleven, 43, 1-16.

Butt, A. (2011). The country town and the city network: The expanding commuter field of Melbourne. In J. Martin \& T. Budge (Eds.), The sustainability of Australia's country towns: Renewal, Renaissance, Resilience. Ballarat, VIC: VURRN Press.

Federation of Ethnic Communities' Councils of Australia. (2009). African Australians (Human Rights and Social Inclusion) Discussion Paper. Retrieved from http://www.fecca.org.au/images/stories/documents/Submissions/2009/submissions 2009023. pdf

Grace, H., Hage, G., Johnson, L., Langsworth, J., \& Symonds, M. (1997). Home/world: Space, community and marginality in Sydney's west. Annandale: Pluto Press.

Hage, G. (1997). at home in the entrails of the west. In H. Grace, G. Hage, L. Johnson, J. Langsworth, \& M. Symonds (Eds.), Home/world (pp. 99-154). Annandale: Pluto Press.

Horgan, M. (2012). Strangers and strangership. Journal of Intercultural Studies, 33(6), 607-622. doi:10.1080/07256868.2012.735110

Jensen, J., Perry, D., \& Halastanis, K. (2007). Castlemaine Sudanese_Burundi Community. Paper presented at the ECCV 2007 Conference 'Regional Settlement for Migrants and Refugees', Bendigo.

Lobo, M. (2010a). Interethnic understanding and belonging in suburban Melbourne. Urban Policy \& Research, 28(1), 85-99.

Lobo, M. (2010b). Reimagining citizenship suburban Australia. Saarbrucken: Lambert Academic.

Major, J., Wilkinson, J., Langat, K., \& Santoro, N. (2013). Sudanese young people of refugee background in rural and regional Australia: Social capital and education success. Australian and International Journal of Rural Education, 23(3), 95-105.

Marotta, V. P. (2001). Modernity, sociology and strangehood: The idea of the stranger in the work of Simmel, Park and Bauman. (PhD), La Trobe, Bundoora.

Marotta, V. P. (2008). Multicultural places and the idea of home. Paper presented at the TASA, Melbourne.

McDonald, B., Gifford, S., Webster, K., Wiseman, J., \& Casey, S. (2008). Refugee resettlement in regional and rural Victoria: Impacts and policy issues. Retrieved from http://refugeehealthnetwork.org.au/refugee-resettlement-in-regional-and-rural-victoriaimpacts-and-policy-issues/

McDonald, B., Gifford, W., Gifford, S. M., Webster, K., Wiseman, J., \& Casey, S. (2009). Resettling refugees in rural and regional Australia: Learning from recent policy and program initiatives. The Australian Journal of Public Administration, 68(1), 97-111. doi:10.1111/j.1467-8500.2008.00611.x

Ossewaarde, M. (2007). Cosmopolitanism and the society of strangers. Current Sociology, 55(3), 367-388. doi:10.1177/0011392107076081

Ratnayake, R. (2017). Sense of safety in public spaces: University student safety experiences in an Australian regional city. Rural society, 26(1), 69-84. doi:10.1080/10371656.2017.1284616 
Taylor, J. (2005). Refugees and regional settlement: Win-win? Paper presented at the Australian Social Policy Conference, New South Wales.

Wickramaarachchi, N., \& Burns, E. (2017). Local newspaper reporting humanitarian migrants' settlement experience in an Australian country town. Rural society, 26(2), 125-142. doi:10.1080/10371656.2017.1331532

Wickramaarachchi, N., \& Butt, A. (2014). Motivations for retention and mobility: Pathways of skilled migrants in regional Victoria, Australia. Rural society, 23(3), 188-197.

Wise, A. (2010). Sensuous multiculturalism: Emotional landscapes of inter-ethnic living in Australian suburbia. Journal of Ethnic and Migration Studies, 36(6), 917-937. doi:10.10801.3691831003643355

Wise, A., \& Velayutham, S. (Eds.). (2009). Introduction: Multiculturalism and everyday life. England: Palgrave macmillan.

Zournazi, M., \& Hage, G. (2002). 'On the side of life'- Joy and the capacity of being: A conversation with Ghassan Hage. In M. Zournazi (Ed.), Hope: New philosophies for chnage (pp. 150-172). New York: Routledge. 